\title{
molecules
}

ISSN 1420-3049

www.mdpi.com/journal/molecules

Article

\section{Inhibition of GIcNAc-Processing Glycosidases by C-6-Azido-NAG-Thiazoline and Its Derivatives}

\author{
Jana Krejzová ${ }^{1,2, \dagger}$, Petr Šimon ${ }^{1,3, \dagger}$, Lubica Kalachova ${ }^{1}$, Natallia Kulik ${ }^{4}$, Pavla Bojarová ${ }^{1}$, \\ Petr Marhol ${ }^{1}$, Helena Pelantová ${ }^{1}$, Josef Cvačka ${ }^{5}$, Rüdiger Ettrich ${ }^{4}$, Kristýna Slámová ${ }^{1, *}$ \\ and Vladimír Křen ${ }^{1}$
}

1 Institute of Microbiology, Academy of Sciences of the Czech Republic, Vídeňská 1083, 14220 Praha 4, Czech Republic; E-Mails: hoficek@centrum.cz (J.K.); shimon@seznam.cz (P.Š.); kalachova@biomed.cas.cz (L.K.); fialovap@email.cz (P.B.); rtepm@seznam.cz (P.M.); pelantova@biomed.cas.cz (H.P.); kren@biomed.cas.cz (V.K.)

2 Department of Biochemistry and Microbiology, Institute of Chemical Technology Prague, Technická 5, 16628 Praha 6, Czech Republic

3 Institute of Organic Chemistry and Biochemistry, Academy of Sciences of the Czech Republic, Flemingovo nám. 2, 16610 Praha 6, Czech Republic

4 Department of Structure and Function of Proteins, Institute of Nanobiology and Structural Biology of GCRC, Academy of Sciences of the Czech Republic, Zámek 136, 37333 Nové Hrady,

Czech Republic; E-Mails: kulik@nh.cas.cz (N.K.); ettrich@nh.cas.cz (R.E.)

5 Institute of Organic Chemistry and Biochemistry, Academy of Sciences of the Czech Republic, Flemingovo nám. 2, 16610 Praha 6, Czech Republic; E-Mail: cvacka@uochb.cas.cz

$\dagger$ These authors contributed equally to this work.

* Author to whom correspondence should be addressed; E-Mail: slamova.kristyna@gmail.com; Tel.: +420-296-442-766; Fax: +420-296-442-509.

Received: 4 February 2014; in revised form: 6 March 2014 / Accepted: 13 March 2014 / Published: 20 March 2014

\begin{abstract}
NAG-thiazoline is a strong competitive inhibitor of GH20 $\beta$ - $N$-acetylhexosaminidases and GH84 $\beta$ - $N$-acetylglucosaminidases. Here, we focused on the design, synthesis and inhibition potency of a series of new derivatives of NAG-thiazoline modified at the C-6 position. Dimerization of NAG-thiazoline via C-6 attached triazole linkers prepared by click chemistry was employed to make use of multivalency in the inhibition. Novel compounds were tested as potential inhibitors of $\beta$ - $N$-acetylhexosaminidases from Talaromyces flavus, Streptomyces plicatus (both GH20) and $\beta$ - $N$-acetylglucosaminidases
\end{abstract}


from Bacteroides thetaiotaomicron and humans (both GH84). From the set of newly prepared NAG-thiazoline derivatives, only C-6-azido-NAG-thiazoline displayed inhibition activity towards these enzymes; C-6 triazole-substituted NAG-thiazolines lacked inhibition activity against the enzymes used. Docking of C-6-azido-NAG-thiazoline into the active site of the tested enzymes was performed. Moreover, a stability study with GlcNActhiazoline confirmed its decomposition at $\mathrm{pH}<6$ yielding 2-acetamido-2-deoxy-1-thio- $\alpha / \beta$ D-glucopyranoses, which presumably dimerize oxidatively into S-S linked dimers; decomposition products of NAG-thiazoline are void of inhibitory activity.

Keywords: NAG-thiazoline; enzyme inhibition; $O$-GlcNAcase; click chemistry; azide; $\beta$ - $N$-acetylhexosaminidase

\section{Introduction}

NAG-thiazoline (2'-methyl-2-acetamido-2-deoxy- $\alpha$-D-glucopyranosyl-[2,1-d]- $\Delta 2$ '-thiazoline, 1) [1] is generally recognized as a strong competitive inhibitor of GH20 $\beta$ - $N$-acetylhexosaminidases and GH84 $\beta$ - $N$-acetylglucosaminidases ( $O$-GlcNAcases) [2] based on mimicking of the oxazoline transition state during the hydrolytic cleavage of $\mathrm{N}$-acetylglucosamine (GlcNAc) moiety from various substrates. Small molecule inhibitors of $\beta$ - $N$-acetylhexosaminidases are very helpful tools in the studies of their physiological effects in vivo. However, only in case they are highly selective for just one of these enzyme groups, false observations caused by undesired inhibition of all functionally related enzymes may be avoided. Understanding the mechanism and localization of these structurally and functionally related glycosidases can help in diagnosis and treatment of serious neurodegenerative disorders such as Alzheimer's, Tay-Sachs' or Sandhoff's diseases [3,4].

A kinetic study with NAG-thiazoline and a series of its derivatives with extended $N$-acyl moieties demonstrated that both types of human $\beta-N$-acetylhexosaminidases (GH20 and 84 ) are inhibited by thiazoline 1 in a very similar way $\left(\mathrm{K}_{\mathrm{I}} 70 \mathrm{nM}\right)$, while the $N$-acyl-modified analogues of $\mathbf{1}$ are generally weaker inhibitors displaying high selectivity towards $O$-GlcNAcase [5]. Several more series of various derivatives based on the NAG-thiazoline scaffold have been introduced, e.g., a set of NAG-thiazolines bearing substituents of the thiazoline ring [6], C-1 homologated thiazolines [7], and a series of C-6-acylated analogues of NAG-thiazoline [8]; however, none of those derivatives ever reached the inhibition potency of the parent compound 1. Detailed kinetic and structural studies of $O$-GlcNAcases have enabled the design of the so far most potent and selective NAG-thiazoline-based inhibitor of human $O$-GlcNAcase called thiamet-G, which displays a 37,000-fold higher selectivity for $O$-GlcNAcase $\left(\mathrm{K}_{\mathrm{I}} 21 \mathrm{nM}\right)$ over lysosomal $\beta$ - $N$-acetylhexosaminidase $\left(\mathrm{K}_{\mathrm{I}} 750 \mu \mathrm{M}\right)$. This inhibitor has proved its selective effect in vivo and is currently tested as a potential Alzheimer's therapeutics blocking pathogenic hyperphosphorylation of protein tau $[3,9]$.

In the present work we focused on the design, synthesis and inhibition potency of a series of new derivatives of NAG-thiazoline (1) modified at the C-6 position of the pyranose ring first with the azido-group (2), which was consequently transformed into substituted triazole-derivatives using click chemistry (3-8). Moreover, two triazole-derivatives were dimers, aiming at a possible multivalency 
effect in enzyme inhibition $\mathbf{( 9 , 1 0 )}$. Two GH20 $\beta$ - $N$-acetylhexosaminidases and two GH84 $\beta$ - $N$-acetylglucosaminidases were used as representatives of these glycosidase families in inhibition assays with the prepared NAG-thiazoline derivatives. The results of the inhibition experiments were correlated with molecular dynamics simulations of the substrate and the new inhibitor C-6-azidoNAG-thiazoline (2) docked into crystal structures and homology models of enzymes used in the inhibition tests.

\section{Results and Discussion}

\subsection{Synthesis of NAG-Thiazoline Derivatives $\mathbf{2}-\mathbf{1 0}$}

NAG-thiazoline (1), prepared from 2-acetamido-2-deoxy-1,3,4,6-tetraacetyl- $\beta$-D-glucopyranoside using Lawesson's reagent followed by Zemplén deacetylation [1], was used as starting material for derivatizations. Compound 1 was activated at $\mathrm{C}-6$ by tosylation with $\mathrm{TsCl}$ in pyridine followed by the reaction with $\mathrm{NaN}_{3}$ in DMF [10] and the obtained azido derivative 2 was then treated with respective alkyne derivatives under $\mathrm{Cu}^{+}$catalysis (Cu-AAC, copper catalyzed azide-alkyne cycloaddition). Eight new derivatives of NAG-thiazoline attached via triazole ring at C-6 were prepared. Two structures of these series are dimeric NAG-thiazolines bridged by aliphatic or etheric linkers (Scheme 1), which are non-hydrolysable in vivo.

Scheme 1. Synthetic pathway.

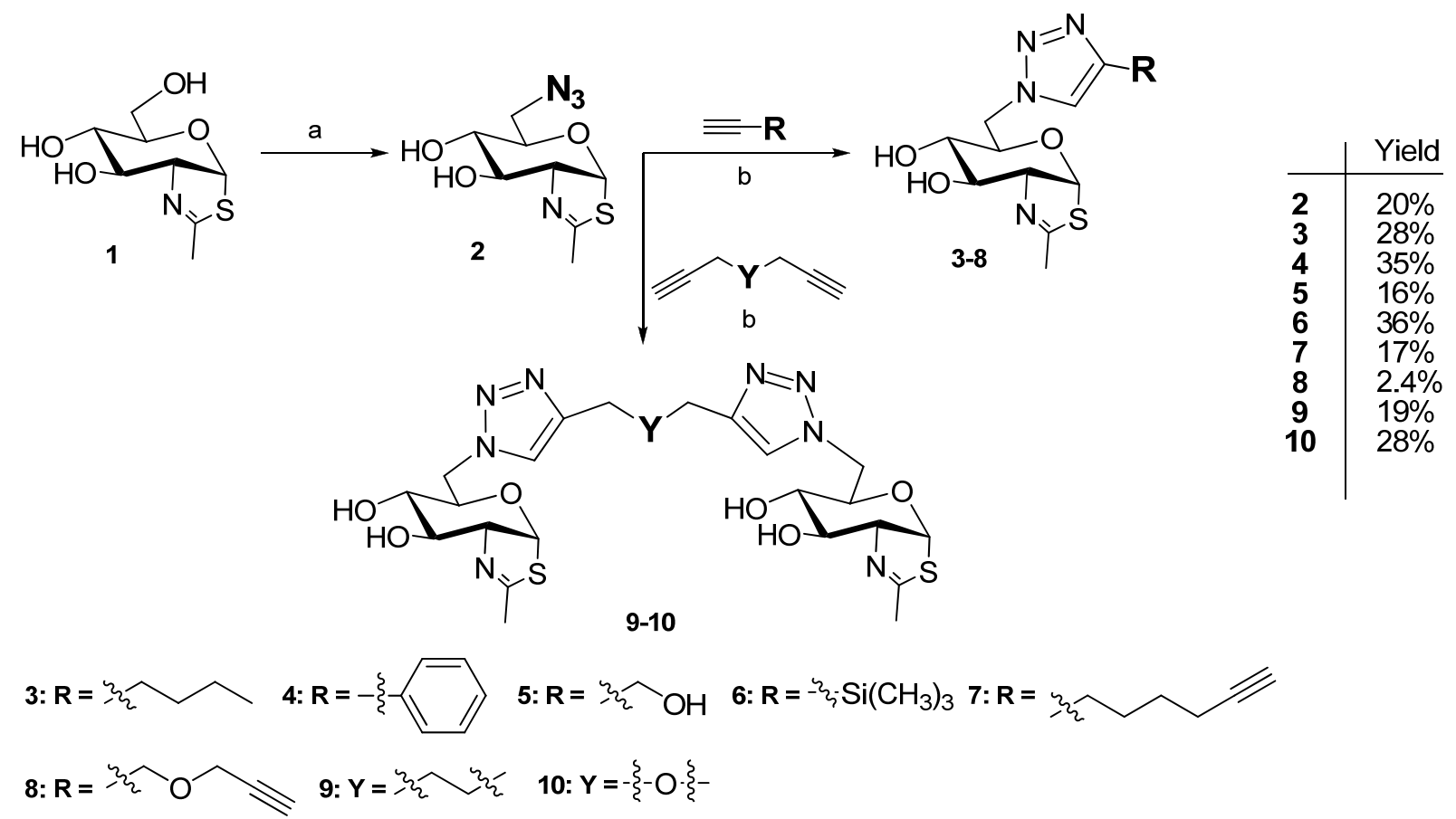

Reagents and Conditions: (a) TsCl, pyridine, $20^{\circ} \mathrm{C}, 1 \mathrm{~h}$; then $\mathrm{NaN}_{3}, \mathrm{DMF}, 60^{\circ} \mathrm{C}, 16 \mathrm{~h}$; (b) $\mathrm{CH}_{3} \mathrm{CN}$, DIPEA, CuI, $20^{\circ} \mathrm{C}, 16 \mathrm{~h}$.

Excess of monofunctional alkyne afforded triazole derivatives substituted by a sugar unit at N-1 of the triazole moiety (Scheme 1). Half equivalent of the bifunctional alkyne linked two NAG-thiazoline moieties in an analogous way. The influence of the respective linkers attached to the triazole moiety 
was evaluated to select the optimal linker type for multivalent presentation of this inhibitor, finally, aliphatic (octa-1,7-diyne) and etheric (dipropargylether) dialkynes were employed. Reaction conditions of $\mathrm{Cu}-\mathrm{AAC}$ were improved with respect to the present acido-labile thiazoline moiety; the optimized reactions catalyzed by $\mathrm{CuI}$ in acetonitrile and DIPEA afforded good yields.

\subsection{Stability of the NAG-Thiazoline Parent Structure 1}

Since some GlcNAc-processing enzymes such as fungal $\beta$ - $N$-acetylhexosaminidases optimally act (and are usually investigated) under acidic conditions [11] we examined the fate of NAG-thiazoline at $\mathrm{pH}$ below 7 at $35^{\circ} \mathrm{C}$. As a result, the acid-labile thiazoline ring quickly (within minutes) decomposed at $\mathrm{pH}<6$; at $\mathrm{pH} 6$ the stability was safely acceptable for experiments that last maximally up to one hour. A thorough HPLC monitoring of NAG-thiazoline stability at $\mathrm{pH} 6.5$ revealed a quasi-linear decomposition rate of ca $1 \%$ per hour, decreasing to $0.5 \%$ per hour after $3 \mathrm{~h}$. After $24 \mathrm{~h}$, the content of intact NAG-thiazoline decreased to ca $70 \%$ of the original concentration. This demonstrates that the use of NAG-thiazoline for long term experiments (in the range of days) at $\mathrm{pH}<7$ is unadvisable since the decomposition rate is not negligible under these conditions; at lower $\mathrm{pH}$ the decomposition is expected to proceed much faster.

The direct decomposition product of NAG-thiazoline is 2-acetamido-2-deoxy-1-thio- $\alpha$-Dglucopyranose (11a). Besides expected mutarotation to its $\beta$-anomer 11b, both these compounds rapidly undergo spontaneous oxidation by air oxygen to form a rich mixture of products, presumably of GlcNAc-S-(1↔1)-S-GlcNAc type $(\mathrm{m} / \mathrm{z}=456)$ (Scheme 2$)$. Importantly, neither the hydrolytic products 11a and 11b nor the originating oxidation products displayed any inhibition effects comparable to thiazoline $\mathbf{1}$ (as shown in Talaromyces flavus $\beta$ - $N$-acetylhexosaminidase). After application of dithiothreitol, the oxidation mixture was reduced back to 11a and 11b, as confirmed by in situ NMR and HPLC experiments.

Scheme 2. Decomposition products of NAG-thiazoline 1; 2-acetamido-2-deoxy-1-thio- $\alpha$ D-glucopyranose (11a), its $\beta$-anomer 11b formed by mutarotation and a mixture of oxidation products (tentative structure) spontaneously originating by the action of air oxygen.

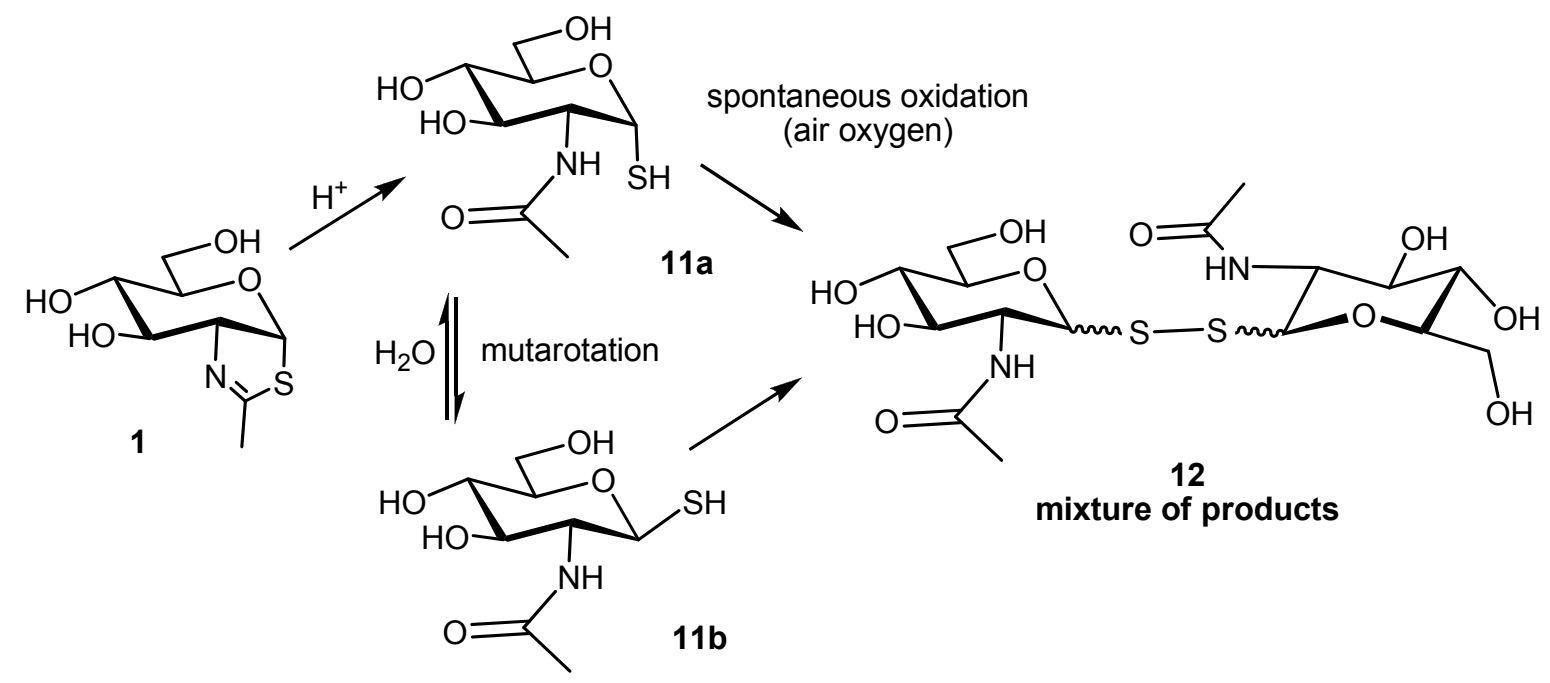




\subsection{Inhibiton of GH2O and GH84 Glycosidases with NAG-Thiazoline Derivatives}

The parent compound NAG-thiazoline (1) is a well established competitive mechanism-based inhibitor of the GH20 $\beta$ - $N$-acetylhexosaminidases and GH84 $\beta$ - $N$-acetylglucosaminidases [1,5]. Based on its structure, a number of analogues were designed and tested as $\beta$ - $N$-acetylhexosaminidase inhibitors, including various $N$-acyl-derivatives $[3,5,6]$ and the C-6-acylated derivatives [8]. Thus, the prepared monomeric $(\mathbf{2 - 8})$ and dimeric $(\mathbf{9 , 1 0})$ derivatives of NAG-thiazoline bearing the azido or triazole moiety at C-6 were designed as potential competitive inhibitors of GlcNAc-processing enzymes from the families 20 and 84 of glycoside hydrolases.

One bacterial and one eukaryotic model enzyme of each glycosidase family were selected for the inhibition study: the GH20 $\beta$ - $N$-acetylhexosaminidases from Streptomyces plicatus (bacterial) and Talaromyces flavus (fungal) and GH84 $\beta$ - $N$-acetylglucosaminidases from Bacteroides thetaiotaomicron (bacterial) and humans. Bacterial and human enzymes were prepared by heterologous expression in E. coli using standard procedures and purified by metal affinity chromatography from the lysed cells. $\beta$ - $N$-Acetylhexosaminidase from $T$. flavus was expressed extracellularly in Pichia pastoris and purified by cation exchange chromatography from the culture media. All new compounds were tested with all of the enzymes but only the C-6-azido-NAG-thiazoline (2) displayed inhibition activity towards these enzymes; the triazole-substituted NAG-thiazolines lacked any inhibition activity against the enzymes used. The results of the Michaelis-Menten kinetic experiments with NAG-thiazoline (1) and C-6-azido-NAG-thiazoline (2) using $p$ NP- $\beta$-GlcNAc as a substrate are summarized in Table 1.

Table 1. Inhibition of $\beta-N$-acetylhexosaminidases and $\beta$ - $N$-acetylglucosaminidases by NAG-thiazoline 1 and its C-6-azido derivative 2 (substrate $p$ NP- $\beta$-GlcNAc; $p H 7 ; 25{ }^{\circ} \mathrm{C}$ ).

\begin{tabular}{cccc}
\hline & & $\mathbf{K}_{\mathbf{I}}[\boldsymbol{\mu M}]$ & $\mathbf{K}_{\mathbf{I}}[\boldsymbol{\mu M}]$ \\
\cline { 3 - 4 } Enzyme & & NAG-thiazoline (1) & $\mathbf{C - 6 - a z i d o - N A G - t h i a z o l i n e ~ ( 2 ) ~}$ \\
\hline $\boldsymbol{\beta}$ - $\boldsymbol{N}$-acetylhexosaminidase & T. flavus & $42.7 \pm 1.9$ & $211.9 \pm 16.3$ \\
& S. plicatus & $24 \pm 5$ & n.d. \\
\multirow{2}{*}{$\boldsymbol{O}$-GlcNAcase } & B. thetaiotaomicron & $0.029 \pm 0.003$ & $3.1 \pm 0.3$ \\
& human & $0.18 \pm 0.03$ & $19.3 \pm 11.9$ \\
\hline
\end{tabular}

n.d. $=$ not determined.

The inhibition constants presented in Table 1 clearly indicate the stronger effect of both inhibitors with the GH84 $\beta$ - $N$-acetylglucosaminidases, while with GH20 $\beta$ - $N$-acetylhexosaminidases the inhibition activity of the tested inhibitors is significantly (up to three orders of magnitude) lower or even negligible as in the case of bacterial $\beta$ - $N$-acetylhexosaminidase and the azido-derivative 2 . However, in all cases the newly designed C-6-azido-NAG-thiazoline (2) performed somewhat worse than the original NAG-thiazoline; with $O$-GlcNAcases the inhibition constants appeared approximately hundred times higher. We can conclude that both tested inhibitors are highly selective for the GH84 glycosidases while the C-6-azido derivative 2 remains less effective than the parent compound $\mathbf{1}$. Similar result has been shown previously with other structurally modified NAG-thiazolines $[5,6,8]$ with the only exception of the potential Alzheimer's therapeutic thiamet-G [3]. Thus, new pathways are still to be found that lead to derivatives conquering the inhibition potency of 1 . 


\subsection{Interactions and Calculated Binding Energies of C-6-azido-NAG-thiazoline (2) in The Active} Site of Enzymes

To obtain a deeper understanding of the inhibition on a molecular scale, we performed molecular docking and consequent molecular dynamics simulations of inhibitors $\mathbf{1}$ and $\mathbf{2}$ and the artificial substrate $p$ NP- $\beta$-GlcNAc. In molecular dynamics simulations the solvent is explicitly included, and after initial equilibration at the given temperature the full conformational space of the substrate/inhibitor-enzyme complexes is sampled, which significantly improves further analysis of the initial docked poses and gives a more realistic understanding of the substrate-enzyme interaction. In the simulations substrate/inhibitor-enzyme complexes adapted to the environment and reached equilibrium around $5 \mathrm{~ns}$ as estimated by root mean square deviation, and only the production run hereafter was used for analysis. For energy calculations complex conformations from the last 2 ns of the production runs were used to ensure that they represent the equilibrated substrate/inhibitor-enzyme complex. The binding energy hereby is estimated as the sum of the intermolecular energy calculated by the force field and the torsional free-energy penalty. Hereby, the intermolecular energy includes terms for electrostatic energy, hydrogen bonding, van der Waals interactions, and a desolvation energy estimate. A comparison of the calculated binding energies and type of interactions for the various complexes is presented in Table 2. The strongest binding was observed in the complex of the bacterial $O$-GlcNAcase and C-6-azido-NAG-thiazoline (2), whose binding energy is significantly lower than the one calculated for the substrate and also inhibitor 1 . The interaction of the inhibitor with the active site of bacterial $O$-GlcNAcase is enhanced by two $\pi$-cation interactions, one by the azido-group at the C- 6 atom with residues Tyr345 and His433, the other one by the positively charged nitrogen atom in the oxazolinium ring involving Tyr282 and Trp337 compared to $p$ NP- $\beta$-GlcNAc (Figure 1). However, His433 is not conserved throughout the family and in human $\beta-N$-acetylglucosaminidase this position is filled by the smaller and neutral valine in the vicinity of the inhibitor's azido-group.

Table 2. Binding energies * in the molecular dynamics simulations calculated by AutoDock (number of hydrogen bonds throughout the simulations).

\begin{tabular}{|c|c|c|c|c|}
\hline \multicolumn{2}{|c|}{ Enzyme } & \multirow{2}{*}{$\begin{array}{l}\text { NAG-thiazoline } \\
\text { (1) [kcal/mol] } \\
-9.22(6-7)\end{array}$} & \multirow{2}{*}{$\begin{array}{c}\text { C-6-azido-NAG- } \\
\text { thiazoline (2) } \\
\text { [kcal/mol] }\end{array}$} & \multirow{2}{*}{ 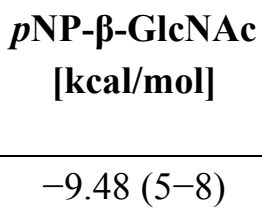 } \\
\hline$\beta-N-$ & S. plicatus & & & \\
\hline acetylhexosaminidase & T. flavus & $-7.63(3-6)$ & $-7.71(3-4)$ & $-10.19(6-9)$ \\
\hline \multirow[t]{2}{*}{$O$-GlcNAcase } & B. thetaiotaomicron & $-7.14(4-5)$ & $-8.65(4-5)$ & $-7.75(6-7)$ \\
\hline & human & $-6.42(3-4)$ & $-7.16(3-4)$ & $-7.45(5-6)$ \\
\hline
\end{tabular}

* Lower binding energy corresponds to better binding.

Surprisingly, inhibitor $\mathbf{2}$ appeared to bind better than $\mathbf{1}$ into the active site of both bacterial and human $\beta$ - $N$-acetylglucosaminidases. This improvement could be explained by $\pi$-cation interaction of C-6 azido-group with aromatic residues (Figure 2). In the case of human GH84 enzyme this interaction is weaker and occurs just with Tyr286 (corresponds to Tyr345 in bacterial GH84). This together with the loss of a hydrogen bonding interaction of human Asn280 with C-6-azido-NAG-thiazoline (2) caused the significantly weaker binding of inhibitor 2 (Figure 3 ) to human $\beta$ - $N$-acetylglucosaminidase. 
Figure 1. C-6-Azido-NAG-thiazoline (2) (A) and substrate $p N P-\beta-G l c N A c(B)$ in the active site of bacterial $\beta-N$-acetylglucosaminidase (B. thetaiotaomicron). Color scheme: carbon atom-cyan, oxygen-red, nitrogen-blue, sulfur-green, hydrogens are omitted; hydrogen bonds-green dashed line with marked donor-acceptor length in Ångstroms; residues participating in $\pi$-cation interaction are shown schematically.

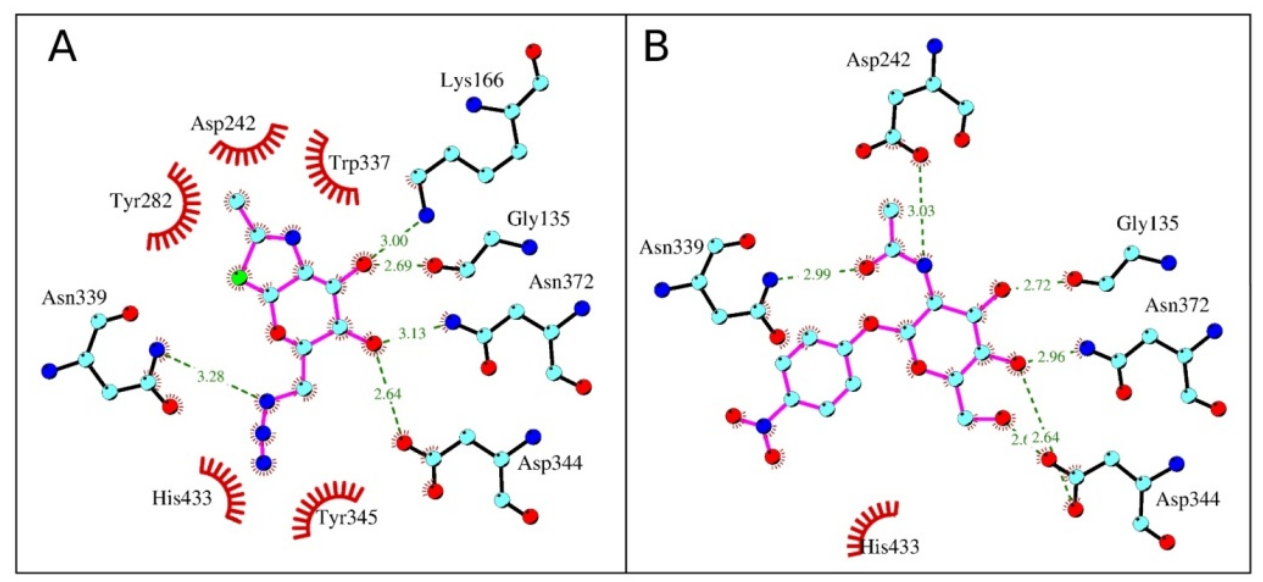

Figure 2. Overlay of NAG-thiazoline (1) and C-6-azido-NAG-thiazoline (2) and in the active site of bacterial $\beta-N$-acetylglucosaminidase. Bacterial residues and C-6-azido-NAGthiazoline are labeled in vivid colors using the color scheme analogous to Figure 1. Bacterial residues and NAG-thiazoline are shown in grey. Common residues participating in hydrogen bond or $\pi$-cation interactions are in circles.

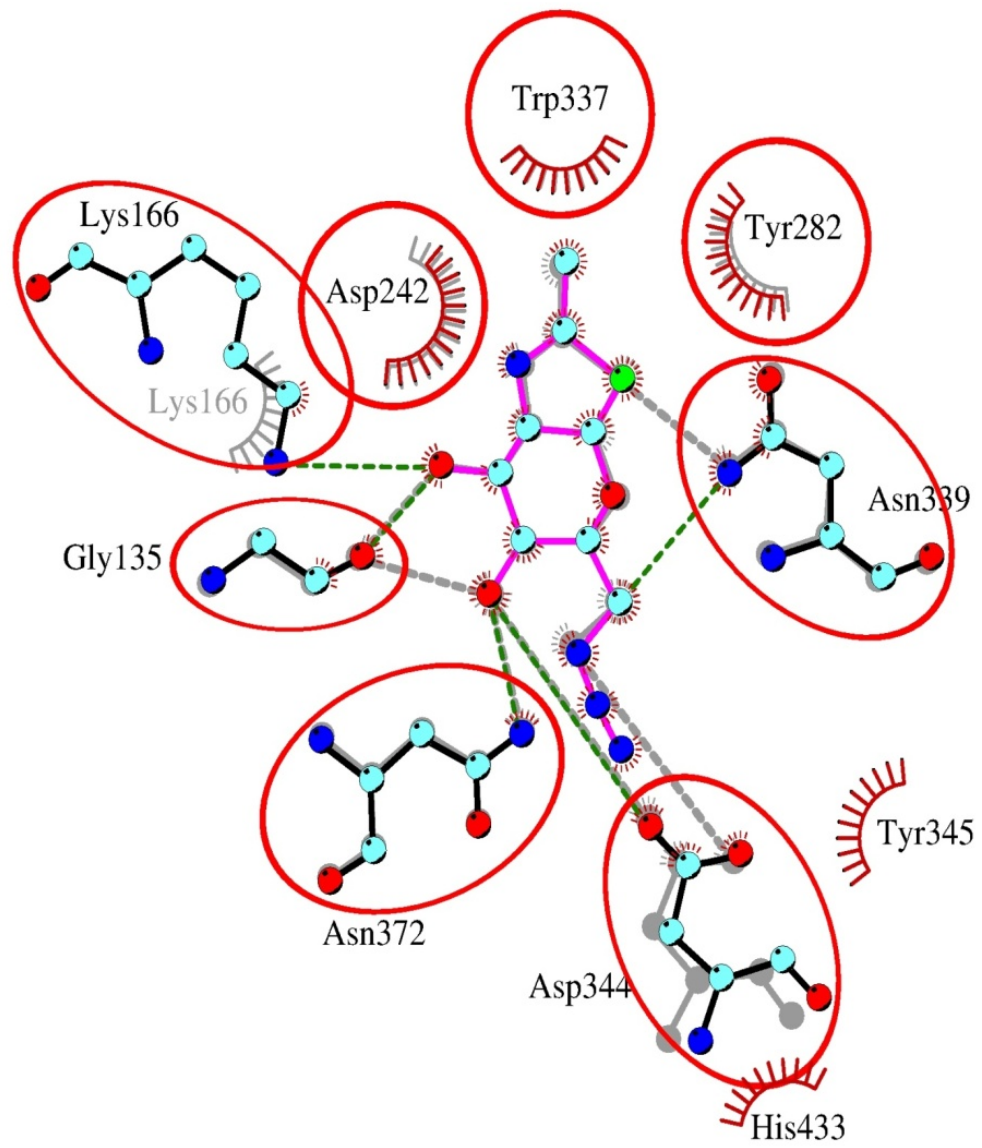


Figure 3. Overlay of C-6-azido-NAG-thiazoline (2) in the active site of human and bacterial $\beta$ - $N$-acetylglucosaminidases. Bacterial residues are labeled in the upper lines, human Lys98 and Asn280 are shown schematically only, as they are not in hydrogen bond distance to the inhibitor. Bacterial active site amino acid residues are shown in color, human enzyme is presented in grey. Residues His433 (magenta) in the bacterial enzyme and the corresponding Val376 (yellow) in the human enzyme are shown in stick representation. Val376 is unable to form a $\pi$-cation interaction with the azido-group (N9-N10-N11) of 2. Other interactions are similar to the bacterial enzyme. Color scheme is the same as in Figure 1.

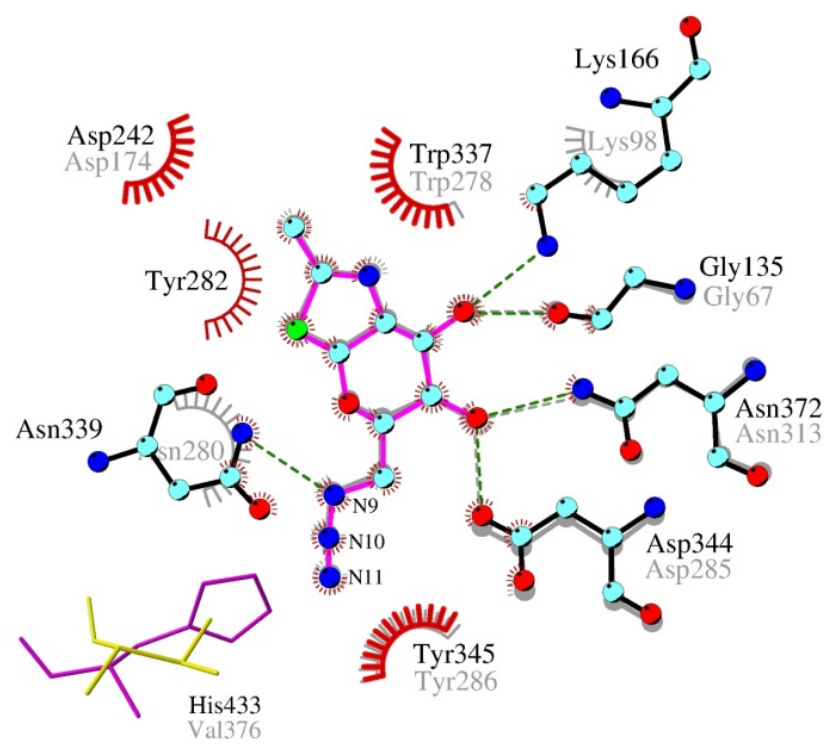

A different character of interactions was observed in the case of GH20 $\beta$ - $N$-acetylhexosaminidases. Here, the azido-group of inhibitor $\mathbf{2}$ docked into the active site is not surrounded by aromatic residues like in bacterial $O$-GlcNAcase, weakening the stability of the resulting complexes. Generally, the affinity of $\beta$ - $N$-acetylhexosaminidases to modified NAG-thiazoline $\mathbf{2}$ is lower than to the substrate that has more hydrogen bonding partners and a $\pi-\pi$ stacking interaction of the $p$-nitrophenyl group with tryptophan residues (Figure 4A). In the fungal enzyme, the C-3 hydroxyl group of 2 contributes to one additional hydrogen bond with Glu322 and Trp509. Again, residue Glu322 is not conserved throughout the family and in the bacterial $\beta$ - $N$-acetylhexosaminidase a valine is present in this position. Equilibrium orientation of the azido-group in C-6 modified NAG-thiazoline in the active site of bacterial GH20 is different from NAG-thiazoline and substrate, because orientation of some residues in the vicinity of C-6 atom is changed to accommodate the azido-group (Figure 4B), which explains the minor potential of compound $\mathbf{2}$ to inhibit this bacterial enzyme. In the case of T. flavus enzyme, the equilibrium orientations of inhibitor $\mathbf{2}$ and substrate were similar and did not initiate distortions in the vicinity of the C-6 atom (Figure 5).

Overall, the results of molecular docking appear to be in a good correlation with the performed kinetic experiments, predicting the best inhibition for bacterial $O$-GlcNAcase and suggesting a molecular explanation for the undetermined inhibition constant with bacterial $\beta$ - $N$-acetylhexosaminidase. These results give us an idea about potency of the mentioned enzymes to tolerate modifications for future inhibitor constructions. 
Figure 4. Overlay of $p$ NP- $\beta$-GlcNAc and C-6-azido-NAG-thiazoline (2) docked into the active site of bacterial $\beta$ - $N$-acetylhexosaminidase (S. plicatus). (A) Hydrogen bond interaction in the active site. Color scheme is like in Figure 1. Enzyme with docked $p$ NP- $\beta$-GlcNAc is shown in color and C-6-azido-NAG-thiazoline in grey. (B) Active site amino acids changed orientation during MD with C-6-azido-NAG-thiazoline (yellow color). Enzyme and $p$ NP- $\beta$-GlcNAc are shown in magenta. Distances between corresponding atoms ( $\AA$; in blue) of identical residues are labeled.

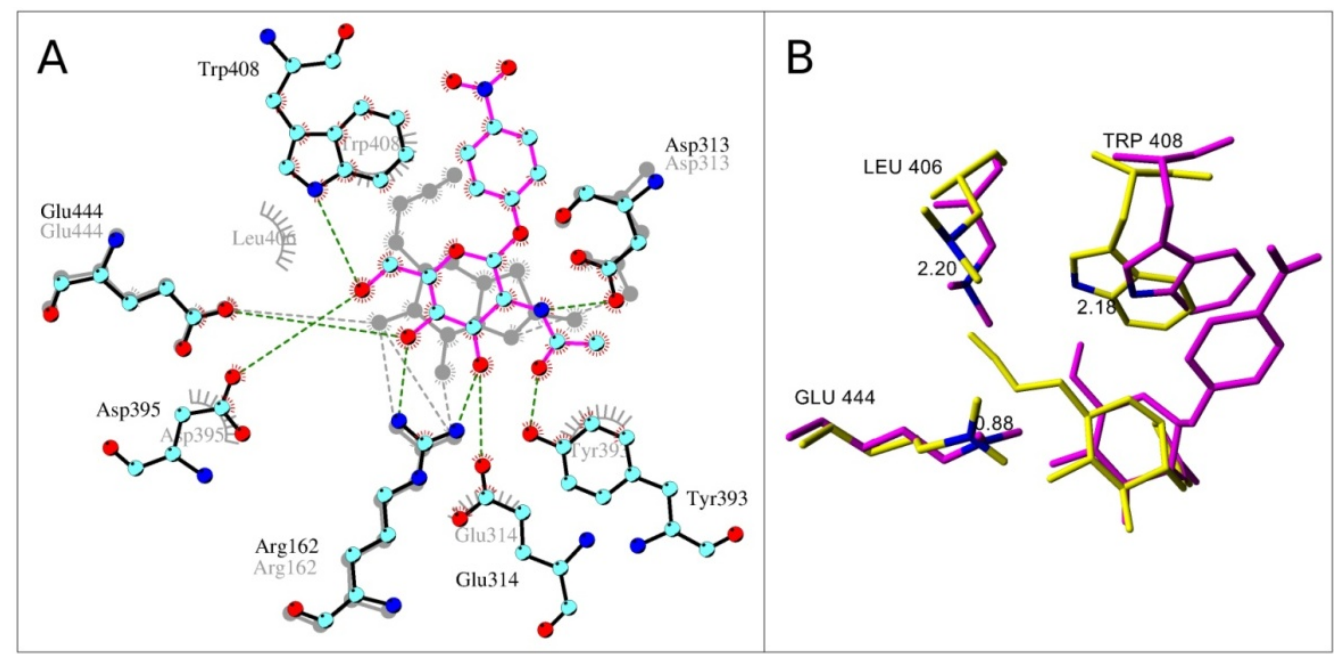

Figure 5. Overlay of C-6-azido-NAG-thiazoline (2) in the active site of $\beta$ - $N$-acetylhexosaminidases from $T$. flavus (in color, active site amino acids are labeled in the upper line) and $S$. plicatus (grey, active site amino acids are labeled in the lower line). Common amino acid residues participating in the interaction are emphasized by circles. Trp408 from S. plicatus contributes only to the hydrophobic interaction with the inhibitor. Due to the slightly different orientation of the inhibitor in the active site of both enzymes, Arg162 from S. plicatus contributes to hydrogen bonds with atoms O-3 and O-4, while Arg218 (from the T. flavus enzyme) is able to form just one hydrogen bond with the O-3 atom.

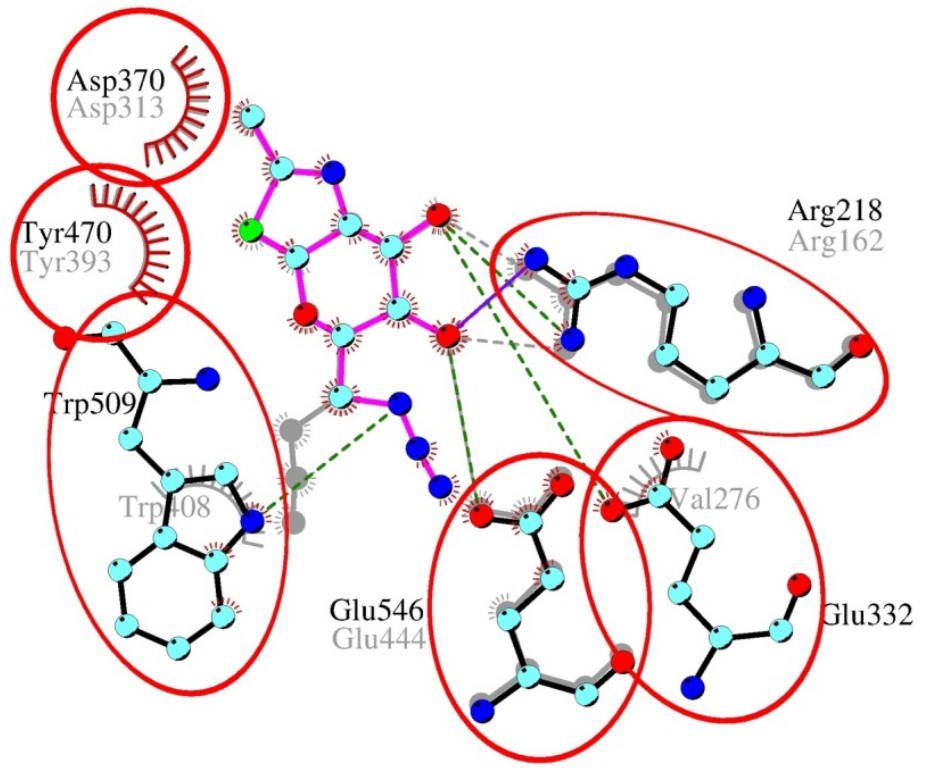




\section{Experimental}

\subsection{General Methods}

All chemicals were purchased from Sigma-Aldrich (Prague, Czech Republic). Reactions were monitored by TLC with pre-coated silica gel $60 \mathrm{~F}_{254}$ aluminum sheets from Merck (Prague, Czech Republic), detected with UV light and/or charred with sulfuric acid $\left(5 \% \mathrm{H}_{2} \mathrm{SO}_{4}\right.$ in EtOH). Compounds were purified by column flash chromatography with silica gel 60 (230-240 mesh, Merck). Solvents were distilled and dried according to the standard procedures before use.

\subsection{NMR Spectroscopy}

NMR spectra were recorded on a Bruker Avance III $400 \mathrm{MHz}$ spectrometer $\left(400.00 \mathrm{MHz}\right.$ for ${ }^{1} \mathrm{H}$, 100.58 MHz for ${ }^{13} \mathrm{C}$ at $30{ }^{\circ} \mathrm{C}$ in $\mathrm{CD}_{3} \mathrm{OD}$-compounds 2-10) and a Bruker Avance III $700 \mathrm{MHz}$ spectrometer (700.13 MHz for ${ }^{1} \mathrm{H}, 176.07 \mathrm{MHz}$ for ${ }^{13} \mathrm{C}$ at $30{ }^{\circ} \mathrm{C}$ in $\mathrm{D}_{2} \mathrm{O}$-compounds 11a and 11b). Residual signals of solvent were used as internal standards $\left(\delta_{\mathrm{H}} 3.330 \mathrm{ppm}, \delta_{\mathrm{C}} 49.30 \mathrm{ppm}\right.$ for $\mathrm{CD}_{3} \mathrm{OD}$; $\delta_{\mathrm{H}} 4.508 \mathrm{ppm}$ for $\left.\mathrm{D}_{2} \mathrm{O}\right)$. Carbon chemical shifts in $\mathrm{D}_{2} \mathrm{O}$ were referenced to acetone $\left(\delta_{\mathrm{C}} 30.50 \mathrm{ppm}\right)$. NMR experiments ${ }^{1} \mathrm{H}-\mathrm{NMR},{ }^{13} \mathrm{C}-\mathrm{NMR}$, gCOSY, gHSQC, and gHMBC were performed using the manufacturer's software. ${ }^{1} \mathrm{H}-\mathrm{NMR}$ and ${ }^{13} \mathrm{C}-\mathrm{NMR}$ spectra were zero filled to fourfold data points and multiplied by window function before Fourier transformation. Two-parameter double-exponential Lorentz-Gauss function was applied for ${ }^{1} \mathrm{H}$ to improve resolution and line broadening $(1 \mathrm{~Hz})$ was applied to get better ${ }^{13} \mathrm{C}$ signal-to-noise ratio. Chemical shifts are given in $\delta$-scale with digital resolution justifying the reported values to three $\left(\delta_{\mathrm{H}}\right)$ or two $\left(\delta_{\mathrm{C}}\right)$ decimal places. The full NMR spectra of the newly prepared compounds $\mathbf{2}-\mathbf{1 0}$ are presented in the Supplementary material.

Proton spin systems of thiazoline and triazole-linker moieties were assigned by COSY and by HSQC transferred to carbons; HMBC experiment enabled to join the above mentioned partial structures together. Thiazoline structure was proved by the presence of methyl doublet $(J=2.0$ or $2.1 \mathrm{~Hz})$ correlated in HMBC to carbons $\mathrm{C}-1$ and C-2. Dimer formation (compounds 9 and 10) was unambiguously confirmed by the auto-correlation cross peak of the central carbon of the linker (C-3' for $\mathbf{1 0}$ and C-5' for 9). ${ }^{1} \mathrm{H}$ and ${ }^{13} \mathrm{C}$ NMR spectra of compounds $\mathbf{2 - 1 0}$ are provided in the Supplementary information.

\subsection{Mass Spectrometry}

The exact masses were measured using LTQ Orbitrap XL hybrid mass spectrometer (Thermo Fisher Scientific, Waltham, MA, USA) equipped with an electrospray ion source. The mobile phase consisted of methanol/water (4:1), flow rate $30 \mu \mathrm{L} / \mathrm{min}$, and the samples were injected using a $2-\mu \mathrm{L}$ loop. The mass spectra of positively charged ions were internally calibrated using protonated phthalic anhydride as lock mass. Data were acquired and processed using Xcalibur software (Thermo Fisher Scientific). HRMS spectra of compounds $\mathbf{2 - 1 0}$ are provided in the Supplementary information.

\subsection{Synthesis of NAG-Thiazoline Derivatives $\mathbf{2 - 1 0}$}

6-Azido-1,2-dideoxy-2'-methyl- $\alpha$-D-glucopyrano-[2,1-d]- $\Delta 2$ '-thiazoline (2): 1,2-Dideoxy-2'-methyl- $\alpha$-Dglucopyrano-[2,1-d]- $\Delta 2$ '-thiazoline prepared according to Knapp and coworkers [1] (1, 1 g 4.56 mmol) was 
dissolved in the mixture of dry pyridine $(10 \mathrm{~mL})$ and dry $\mathrm{CH}_{2} \mathrm{Cl}_{2}(10 \mathrm{~mL})$, cooled to $0{ }^{\circ} \mathrm{C}$ and $\mathrm{TsCl}$ ( $1 \mathrm{~g}, 5.25 \mathrm{mmol}$ ) was added. Reaction mixture was stirred $1 \mathrm{~h}$ at room temperature and then $\mathrm{CH}_{2} \mathrm{Cl}_{2}$ $(10 \mathrm{~mL})$ was added. Organic phase was washed twice with $\mathrm{H}_{2} \mathrm{O}$ and dried over $\mathrm{Na}_{2} \mathrm{SO}_{4}$. Solvents were evaporated, the tosylated derivative was dried in vacuo, dissolved in dry DMF $(15 \mathrm{~mL})$ and $\mathrm{NaN}_{3}$ (800 mg, $11.9 \mathrm{mmol}, 2.6 \mathrm{eq}$ ) was added. Reaction mixture was stirred at $60{ }^{\circ} \mathrm{C}$ overnight. Title compound 2 was at first purified by column chromatography (silica gel, EtOAc/MeOH = 9:1). Isolated mixture of expected product 2 and corresponding 3,6-anhydro-derivative were separated by gel filtration using Sephadex LH-20 (GE Healthcare by AP Czech, Prague, Czech Republic) using 80\% $\mathrm{MeOH}$ as an eluent. Product 2 was isolated as a white solid $(223 \mathrm{mg}, 20 \%) .{ }^{1} \mathrm{H}-\mathrm{NMR}(400.00 \mathrm{MHz}$, $\left.\mathrm{CD}_{3} \mathrm{OD}\right): 2.288\left(3 \mathrm{H}, \mathrm{d}, J=2.1 \mathrm{~Hz}, \mathrm{CH}_{3}\right), 3.418(2 \mathrm{H}, \mathrm{m}, \mathrm{H}-6), 3.471(1 \mathrm{H}, \mathrm{m}, \mathrm{H}-5), 3.588(1 \mathrm{H}$, ddd, $J=8.8,3.6,1.0 \mathrm{~Hz}, \mathrm{H}-4) 4.169$ (1H, ddd, $J=4.7,3.6,0.7 \mathrm{~Hz}, \mathrm{H}-3), 4.377$ (1H, dddq, $J=7.0,4.7,1.0$, $2.1 \mathrm{~Hz}, \mathrm{H}-2), 6.394(1 \mathrm{H}, \mathrm{d}, J=7.0 \mathrm{~Hz}, \mathrm{H}-1) .{ }^{13} \mathrm{C}-\mathrm{NMR}$ (100.58 MHz, CD $\left.\mathrm{OD}\right): 20.96\left(\mathrm{CH}_{3}\right), 53.62$ (C-6), 72.67 (C-4), 74.35 (C-3), 75.24 (C-5), 80.83 (C-2), 90.89 (C-1), 170.96 (=C-). HRMS: $\mathrm{C}_{8} \mathrm{H}_{12} \mathrm{O}_{3} \mathrm{~N}_{4} \mathrm{NaS}$ calcd. 267.05223; $\mathrm{m} / z[\mathrm{M}+\mathrm{Na}]^{+}$found 267.05227.

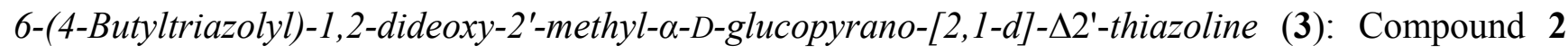
(100 mg, $0.41 \mathrm{mmol})$ was dissolved in the mixture of acetonitrile $(3 \mathrm{~mL})$ and $N, N$ diisopropylethylamine $(0.2 \mathrm{~mL})$. Hexyne $(0.1 \mathrm{~mL})$ and $\mathrm{CuI}(30 \mathrm{mg})$ were added and reaction mixture was stirred overnight at room temperature. The product was isolated after evaporation of solvents by column chromatography ( silica gel, EtOAc- $\mathrm{MeOH}=9: 1$ ). Butyl derivative 3 was isolated as a white solid (38 mg, 28\%). ${ }^{1} \mathrm{H}-\mathrm{NMR}\left(400.00 \mathrm{MHz}, \mathrm{CD}_{3} \mathrm{OD}\right)$ : 0.967 (3H, t, $J=7.4 \mathrm{~Hz}, \mathrm{H}-6$ '), 1.395 (2H, m, H-5'), 1.665 (2H, m, H-4'), 2.237 (3H, d, $\left.J=2.1 \mathrm{~Hz}, \mathrm{CH}_{3}\right), 2,710\left(2 \mathrm{H}, \mathrm{dt}, J=0.6,7.5 \mathrm{~Hz}, \mathrm{H}-3^{\prime}\right), 3.575$ $(2 \mathrm{H}, \mathrm{m}, \mathrm{H}-4, \mathrm{H}-5), 4.245$ (1H, dd, $\Sigma J=6.8 \mathrm{~Hz}, \mathrm{H}-3), 4.380(1 \mathrm{H}, \mathrm{dddq}, \Sigma J=18.1 \mathrm{~Hz}, \mathrm{H}-2), 4.474(1 \mathrm{H}$, dd, $J=14.4,8.0 \mathrm{~Hz}, \mathrm{H}-6 \mathrm{u}), 4.717$ (1H, dd, $J=14.4,1.9 \mathrm{~Hz}, \mathrm{H}-6 \mathrm{~d}), 6.330$ (1H, d, $J=7.0 \mathrm{~Hz}, \mathrm{H}-1)$, $7.695\left(1 \mathrm{H}, \mathrm{t}, J=0.6 \mathrm{~Hz}, \mathrm{H}-1^{\prime}\right) .{ }^{13} \mathrm{C}-\mathrm{NMR}\left(100.58 \mathrm{MHz}, \mathrm{CD}_{3} \mathrm{OD}\right): 14.41\left(\mathrm{C}-6{ }^{\prime}\right), 20.82\left(\mathrm{CH}_{3}\right), 23.39$ (C-5'), 26.18 (C-3'), 32.96 (C-4'), 53.25 (C-6), 73.05 (C-4), 74.17 (C-3), 74.50 (C-5), 80.90 (C-2), 90.66 (C-1), 124.41 (C-1'), 149.36 (C-2'), 170.84 (=C-). HRMS: $\mathrm{C}_{14} \mathrm{H}_{23} \mathrm{O}_{3} \mathrm{~N}_{4} \mathrm{~S}$ calcd. 327.14854; $\mathrm{m} / \mathrm{z}$ $[\mathrm{M}+\mathrm{H}]^{+}$found 327.14848 .

1,2-Dideoxy-2'-methyl-6-(4-phenyltriazolyl)- $\alpha$-D-glucopyrano-[2,1-d]- $\Delta 2^{2}$-thiazoline (4): Compound 4 was prepared analogously as described for the compound $\mathbf{3}$ from azide $\mathbf{2}(100 \mathrm{mg})$ and phenylacetylene $(0.1 \mathrm{~mL})$ yielding title compound 4 as a white solid (50 mg, 35\%). ${ }^{1} \mathrm{H}-\mathrm{NMR}\left(400.00 \mathrm{MHz}, \mathrm{CD}_{3} \mathrm{OD}\right)$ : $2.239\left(3 \mathrm{H}, \mathrm{d}, J=2.1 \mathrm{~Hz}, \mathrm{CH}_{3}\right), 3.631(1 \mathrm{H}, \mathrm{ddd}, J=9.1,3.2,1.0 \mathrm{~Hz}, \mathrm{H}-4), 3.689$ (1H, dddd, $J=9.1,7.7$, 2.5, $0.4 \mathrm{~Hz}, \mathrm{H}-5), 4.269$ (1H, dd, $J=4.7,3.2 \mathrm{~Hz}, \mathrm{H}-3), 4.399$ (1H, dddq, $J=7.0,4.7,1.0,2.1 \mathrm{~Hz}, \mathrm{H}-2)$, $4.598(1 \mathrm{H}, \mathrm{dd}, J=14.4,7.7 \mathrm{~Hz}, \mathrm{H}-6 \mathrm{u}), 4.806(1 \mathrm{H}, \mathrm{dd}, J=14.4,2.5 \mathrm{~Hz}, \mathrm{H}-6 \mathrm{~d}), 6.368(1 \mathrm{H}, \mathrm{d}, J=7.0 \mathrm{~Hz}$, H-1), 7.352 (1H, m, H-para), 7.443 (2H, m, H-meta), 7.825 (2H, m, H-ortho), 8.283 (1H, s, H-1'). ${ }^{13} \mathrm{C}-\mathrm{NMR}$ (100.58 MHz, CD $\left.{ }_{3} \mathrm{OD}\right): 20.92\left(\mathrm{CH}_{3}\right), 53.38$ (C-6), 72.29 (C-4), 74.18 (C-3), 74.39 (C-5), 80.74 (C-2), 90.63 (C-1), 123.60 (C-1'), 126.95 (C-ortho), 129.59 (C-para), 130.23 (C-meta), 131.92 (C-ipso), 148.94 (C-2'), 171.10 (=C-). HRMS: $\mathrm{C}_{16} \mathrm{H}_{19} \mathrm{O}_{3} \mathrm{~N}_{4} \mathrm{~S}$ calcd. 347.11724; m/z [M+H] found 347.11704 . 


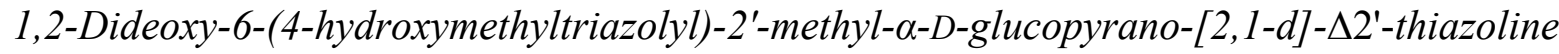

Compound 5 was prepared as described for the compound 3 from azide 2 (100 $\mathrm{mg})$ and propargylalcohol $(0.1 \mathrm{~mL})$ yielding hydroxymethyl derivative 5 as a white solid $(20 \mathrm{mg}, 16 \%)$. ${ }^{1} \mathrm{H}-\mathrm{NMR}$ (400.00 MHz, CD $\mathrm{OD}$ ): $2.241\left(3 \mathrm{H}, \mathrm{d}, J=2.0 \mathrm{~Hz}, \mathrm{CH}_{3}\right), 3.562(1 \mathrm{H}, \mathrm{ddd}, J=9.1,3.3,1.0 \mathrm{~Hz}$, H-4), 3.639 (1H, dddd, $J=9.1,7.9,2.5,0.4 \mathrm{~Hz}, \mathrm{H}-5), 4.222(1 \mathrm{H}, \mathrm{dd}, J=4.6,3.3 \mathrm{~Hz}, \mathrm{H}-3), 4.372(1 \mathrm{H}$, dddq, $J=7.0,4.6,1.0,2.0 \mathrm{~Hz}, \mathrm{H}-2), 4.542(1 \mathrm{H}, \mathrm{dd}, J=14.5,7.9 \mathrm{~Hz}, \mathrm{H}-6 \mathrm{u}), 4.696(2 \mathrm{H}, \mathrm{d}, J=0.6 \mathrm{~Hz}$, H-3'), $4.751(1 \mathrm{H}, \mathrm{dd}, J=14.5,2.5 \mathrm{~Hz}, \mathrm{H}-6 \mathrm{~d}), 6.337(1 \mathrm{H}, \mathrm{d}, J=7.0 \mathrm{~Hz}, \mathrm{H}-1), 7.887(1 \mathrm{H}, \mathrm{t}, J=0.6 \mathrm{~Hz}$, H-1'). ${ }^{13} \mathrm{C}-\mathrm{NMR}\left(100.58 \mathrm{MHz}, \mathrm{CD}_{3} \mathrm{OD}\right): 20.86\left(\mathrm{CH}_{3}\right), 53.26$ (C-6), 56.77 (C-3'), 72.89 (C-4), 74.20 (C-3), 74.39 (C-5), 80.78 (C-2), 90.70 (C-1), 124.41 (C-1'), 149.20 (C-2'), 170.95 (=C-). HRMS: $\mathrm{C}_{11} \mathrm{H}_{17} \mathrm{O}_{4} \mathrm{~N}_{4} \mathrm{~S}$ calcd. 301.09650; $\mathrm{m} / z[\mathrm{M}+\mathrm{H}]^{+}$found 301.09650 .

1,2-Dideoxy-2'-methyl-6-(4-trimethylsilyltriazolyl)- $\alpha$-D-glucopyrano-[2,1-d]- $\Delta 2$ '-thiazoline

(6):

Compound 6 was prepared as described for compound 3 from azide 2 (100 mg) and trimethylsilylacetylene $(0.1 \mathrm{~mL})$ yielding trimethylsilyl derivative 6 as a white solid $(50 \mathrm{mg}, 36 \%)$. ${ }^{1} \mathrm{H}-\mathrm{NMR}\left(400.00 \mathrm{MHz}, \mathrm{CD}_{3} \mathrm{OD}\right): 0.334\left(9 \mathrm{H}, \mathrm{s}, \mathrm{Si}\left(\mathrm{CH}_{3}\right)_{3}\right), 2.261\left(3 \mathrm{H}, \mathrm{d}, J=2.0 \mathrm{~Hz}, \mathrm{CH}_{3}\right), 3.594(1 \mathrm{H}$, ddd, $J=9.2,3.1,0.8 \mathrm{~Hz}, \mathrm{H}-4), 3.641$ (1H, ddd, $J=9.2,7.6,2.3 \mathrm{~Hz}, \mathrm{H}-5), 4.272(1 \mathrm{H}, \mathrm{dd}, J=4.5$, $3.1 \mathrm{~Hz}, \mathrm{H}-3), 4.405$ (1H, m, H-2), $4.569(1 \mathrm{H}, \mathrm{dd}, J=14.4,7.6 \mathrm{~Hz}, \mathrm{H}-6 \mathrm{u}), 4.796(1 \mathrm{H}, \mathrm{dd}, J=14.4,2.3 \mathrm{~Hz}$, H-6d), 6.341 (1H, d, $J=7.0 \mathrm{~Hz}, \mathrm{H}-1), 7.970$ (1H, s, H-1'). ${ }^{13} \mathrm{C}-\mathrm{NMR}\left(100.58 \mathrm{MHz}, \mathrm{CD}_{3} \mathrm{OD}\right):-0.78$ $\left(\mathrm{Si}\left(\mathrm{CH}_{3}\right)_{3}\right), 21.10\left(\mathrm{CH}_{3}\right), 52.77$ (C-6), 72.99 (C-4), 74.27 (C-3), 74.58 (C-5), 80.82 (C-2), 90.61 (C-1), 132.82 (C-1'), 147.47 (C-2'), 171.39 (=C-). HRMS: $\mathrm{C}_{13} \mathrm{H}_{23} \mathrm{O}_{3} \mathrm{~N}_{4} \mathrm{SSi}$ calcd. 343.12546; m/z [M+H] $]^{+}$ found 343.12537 .

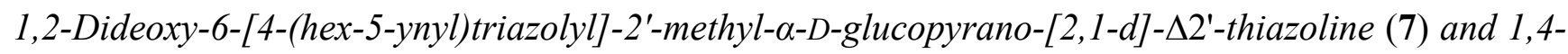

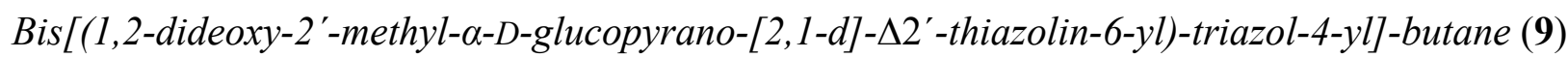

Compound 2 (300 mg, $1.23 \mathrm{mmol})$ was dissolved in the mixture of acetonitrile $(15 \mathrm{~mL})$ and $\mathrm{N}, \mathrm{N}$-diisopropylethylamine $(0.6 \mathrm{~mL})$. Octa-1,7-diyne $(0.08 \mathrm{~mL})$ and $\mathrm{CuI}(150 \mathrm{mg})$ were added and the reaction mixture was stirred overnight at room temperature. The products were isolated after evaporation of solvents by column chromatography (silica gel, $\mathrm{CHCl}_{3} / \mathrm{MeOH}=6: 1$ ). Monomeric derivative 7 was isolated as a white solid $(75 \mathrm{mg}, 17 \%)$ and dimeric derivative 9 was then eluted by methanol gradient as a white solid (69 $\mathrm{mg}, 19 \%)$.

Compound 7: ${ }^{1} \mathrm{H}-\mathrm{NMR}\left(400.00 \mathrm{MHz}, \mathrm{CD}_{3} \mathrm{OD}\right): 1.571\left(2 \mathrm{H}, \mathrm{m}, \mathrm{H}-5^{\prime}\right), 1.802\left(2 \mathrm{H}, \mathrm{m}, \mathrm{H}-4^{\prime}\right), 2.233$ (3H, m, H-6', H-8'), 2.242 (3H, d, J=2.1 Hz, CH $), 2.738$ (2H, dt, J=0.6, 7.4 Hz, H-3'), 3.567 (2H, m, H-4, H-5), 4.249 (1H, m, H-3), 4.382 (1H, dqm, $J=7.0,2.1 \mathrm{~Hz}, \mathrm{H}-2), 4.474$ (1H, m, H-6u), 4.723 (1H, m, H-6d), $6.331(1 \mathrm{H}, \mathrm{d}, J=7.0 \mathrm{~Hz}, \mathrm{H}-1), 7.718\left(1 \mathrm{H}, \mathrm{t}, J=0.6 \mathrm{~Hz}, \mathrm{H}-1\right.$ '). ${ }^{13} \mathrm{C}-\mathrm{NMR}(100.58 \mathrm{MHz}$, $\left.\mathrm{CD}_{3} \mathrm{OD}\right): 19.06\left(\mathrm{C}^{\prime} 6^{\prime}\right), 20.81\left(\mathrm{CH}_{3}\right), 25.95\left(\mathrm{C}-3^{\prime}\right), 29.22$ (C-5'), 29.78 (C-4'), 53.28 (C-6), 70.01 (C-8', 73.08 (C-4), 74.14 (C-3), 74.50 (C-5), 80.81 (C-2), 85.12(C-7'), 90.62 (C-1), 124.51 (C-1'), 149.01 (C-2'), 171.10 (=C-). HRMS: $\mathrm{C}_{16} \mathrm{H}_{22} \mathrm{O}_{3} \mathrm{~N}_{4} \mathrm{NaS}$ calcd. 373.13048; $\mathrm{m} / z[\mathrm{M}+\mathrm{Na}]^{+}$found 373.13033.

Compound 9: ${ }^{1} \mathrm{H}-\mathrm{NMR}\left(400.00 \mathrm{MHz}, \mathrm{CD}_{3} \mathrm{OD}\right): 1.734\left(2 \mathrm{H}, \mathrm{m}, \mathrm{H}-4\right.$ '), $2.228\left(3 \mathrm{H}, \mathrm{d}, J=2.0 \mathrm{~Hz}, \mathrm{CH}_{3}\right)$, 2.754 (2H, m, H-3'), 3.561 (1H, m, H-4), 3.584 (1H, m, H-5), 4.230 (1H, m, H-3), 4.371 (1H, dddq, $J=7.0,4.8,0.8,2.0 \mathrm{~Hz}, \mathrm{H}-2), 4.485$ (1H, m, H-6u), $4.712(1 \mathrm{H}, \mathrm{m}, \mathrm{H}-6 \mathrm{~d}), 6.329(1 \mathrm{H}, \mathrm{d}, J=7.0 \mathrm{~Hz}$, 
$\mathrm{H}-1), 7.717\left(1 \mathrm{H}, \mathrm{t}, J=0.6 \mathrm{~Hz}, \mathrm{H}-1^{\prime}\right) .{ }^{13} \mathrm{C}-\mathrm{NMR}\left(100.58 \mathrm{MHz}, \mathrm{CD}_{3} \mathrm{OD}\right): 20.86\left(\mathrm{CH}_{3}\right), 26.18\left(\mathrm{C}-3^{\prime}\right)$, 30.00 (C-4'), 53.25 (C-6), 73.01 (C-4), 74.20 (C-3), 74.50 (C-5), 80.90 (C-2), 90.70 (C-1), 124.62 (C-1'), $149.03\left(\mathrm{C}-2^{\prime}\right), 170.82$ (=C-). HRMS: $\mathrm{C}_{24} \mathrm{H}_{35} \mathrm{O}_{6} \mathrm{~N}_{8} \mathrm{~S}_{2}$ calcd. 595.21155; m/z [M+H] $]^{+}$found 595.21133.

1,2-Dideoxy-2'-methyl-6-[4-(propargyloxymethyl)-triazolyl]- $\alpha$-D-glucopyrano-[2,1-d]- $\Delta 2$ '-thiazoline (8) and bis\{[(1,2-dideoxy-2'-methyl- $\alpha$-D-glucopyrano-[2,1-d]- $\Delta 2^{\prime}$-thiazoline-6-yl)-triazol-4-yl]-methyl\} ether (10)

Compounds $\mathbf{8}$ and $\mathbf{1 0}$ were prepared as described for the compounds $\mathbf{7}$ and $\mathbf{9}$, respectively, from the azide $2(300 \mathrm{mg})$ and dipropargylether $(0.08 \mathrm{~mL})$ yielding monomeric derivative $\mathbf{8}$ as a white solid (10 $\mathrm{mg}, 2.4 \%$ ) and dimeric derivative $\mathbf{1 0}$ as a white solid (100 $\mathrm{mg}, 28 \%$ ).

Compound 8: ${ }^{1} \mathrm{H}-\mathrm{NMR}\left(400.00 \mathrm{MHz}, \mathrm{CD}_{3} \mathrm{OD}\right): 2.242\left(3 \mathrm{H}, \mathrm{d}, J=2.1 \mathrm{~Hz}, \mathrm{CH}_{3}\right), 2.915(1 \mathrm{H}, \mathrm{t}, J=2.4 \mathrm{~Hz}$, H-6'), 3.568 (1H, m, H-4), 3.610 (1H, m, H-5), 4.211 (2H, d, J=2.4 Hz, H-4'), 4.241 (1H, dd, $J=4.5$, $2.7 \mathrm{~Hz}, \mathrm{H}-3), 4.379$ (1H, dddq, $J=7.0,4.5,0.9,2.1 \mathrm{~Hz}, \mathrm{H}-2), 4.538(1 \mathrm{H}, \mathrm{dd}, J=14.4,7.7 \mathrm{~Hz}, \mathrm{H}-6 \mathrm{u})$, $4.702\left(2 \mathrm{H}, \mathrm{d}, J=0.5 \mathrm{~Hz}, \mathrm{H}-3^{\prime}\right), 4.762(1 \mathrm{H}, \mathrm{dd}, J=14.4,2.3 \mathrm{~Hz}, \mathrm{H}-6 \mathrm{~d}), 6.336$ (1H, d, $\left.J=7.0 \mathrm{~Hz}, \mathrm{H}-1\right)$, $7.954\left(1 \mathrm{H}, \mathrm{t}, J=0.5 \mathrm{~Hz}, \mathrm{H}-1\right.$ '). ${ }^{13} \mathrm{C}-\mathrm{NMR}\left(100.58 \mathrm{MHz}, \mathrm{CD}_{3} \mathrm{OD}\right): 20.83\left(\mathrm{CH}_{3}\right), 53.33(\mathrm{C}-6), 58.28$ (C-4'), 63.47 (C-3'), 72.99 (C-4), 74.16 (C-3), 74.35 (C-5), 76.73 (C-6'), 80.49 (C-5'), 80.83 (C-2), 90.65 (C-1), 126.62 (C-1'), 145.41 (C-2'), 170.93 (=C-). HRMS: $\mathrm{C}_{14} \mathrm{H}_{19} \mathrm{O}_{4} \mathrm{~N}_{4} \mathrm{~S}$ calcd. 339.11215; $m / z[\mathrm{M}+\mathrm{H}]^{+}$found 339.11203 .

Compound 10: ${ }^{1} \mathrm{H}-\mathrm{NMR}$ (400.00 MHz, $\left.\mathrm{CD}_{3} \mathrm{OD}\right): 2.236\left(6 \mathrm{H}, \mathrm{d}, J=2.1 \mathrm{~Hz}, \mathrm{CH}_{3}\right), 3.567(2 \mathrm{H}$, ddd, $J=9.1,2.9,1.0 \mathrm{~Hz}, \mathrm{H}-4), 3.615$ (2H, dddd, $J=9.1,7.6,2.4,0.4 \mathrm{~Hz}, \mathrm{H}-5), 4.238$ (2H, dd, $J=4.5,2.9 \mathrm{~Hz}$, H-3), 4.378 (2H, dddq, $J=7.0,4.5,1.0,2.1 \mathrm{~Hz}, \mathrm{H}-2), 4.549$ (2H, dd, $J=14.4,7.6 \mathrm{~Hz}, \mathrm{H}-6 \mathrm{u}), 4.667$ (4H, d, $J=0.4$ Hz, H-3'), 4.763 (2H, dd, $J=14.4,2.4$ Hz, H-6d), 6.341 (2H, d, $J=7.0$ Hz, H-1), 7.967 $\left(2 \mathrm{H}, \mathrm{t}, J=0.4 \mathrm{~Hz}, \mathrm{H}-1^{\prime}\right) .{ }^{13} \mathrm{C}-\mathrm{NMR}\left(100.58 \mathrm{MHz}, \mathrm{CD}_{3} \mathrm{OD}\right): 20.86\left(\mathrm{CH}_{3}\right), 53.32(\mathrm{C}-6), 64.12$ (C-3'), 72.95 (C-4), 74.15 (C-3), 74.36 (C-5), 80.81 (C-2), 90.68 (C-1), 126.62 (C-1'), 145.73 (C-2'), 170.91 (=C-). HRMS: $\mathrm{C}_{22} \mathrm{H}_{31} \mathrm{O}_{7} \mathrm{~N}_{8} \mathrm{~S}_{2}$ calcd. 583.17516; $\mathrm{m} / z[\mathrm{M}+\mathrm{H}]^{+}$found 583.17503.

\subsection{Stability of NAG-Thiazoline $\mathbf{1}$}

NAG-thiazoline $(1 ; 200 \mathrm{mM})$ was incubated in $50 \mathrm{mM} \mathrm{K} \mathrm{HPO}_{4} / \mathrm{KH}_{2} \mathrm{PO}_{4}$ buffer $\mathrm{pH} 6.5$ at $35^{\circ} \mathrm{C}$ and $850 \mathrm{rpm}$. Aliquots $(10 \mu \mathrm{L})$ were taken at regular time intervals $(30-60 \mathrm{~min})$, mixed with $95 \% \mathrm{CH}_{3} \mathrm{CN}$ $(40 \mu \mathrm{L})$ and analyzed by HPLC. Chromatography was carried out on the Shimadzu Prominence UFLC system (Kyoto, Japan) consisting of DGU-20A mobile phase degasser, two LC-20AD solvent delivery units, SIL-20ACHT cooling autosampler, CTO-10AS column oven and SPD-M20A diode array detector. The HILIC column TSKgel Amide-80 (250 × $4.6 \mathrm{~mm}$ i.d., Tosoh Bioscience, Stuttgart, Germany) was used as a stationary phase. The PDA data were acquired in the 190-320 nm range and the $200 \mathrm{~nm}$ signal was extracted. Gradient elution: mobile phase $\mathrm{A}\left(\mathrm{CH}_{3} \mathrm{CN}\right)$; mobile phase $\mathrm{B}\left(\mathrm{H}_{2} \mathrm{O}\right)$; gradient, 0-2 $\mathrm{min}, 20 \% \mathrm{~B}$; 2-15 $\mathrm{min}, 20 \%-60 \% \mathrm{~B}$; $15-16 \mathrm{~min}, 60 \% \mathrm{~B}, 16-18 \mathrm{~min}, 60 \%-20 \% \mathrm{~B}$, $18-21 \mathrm{~min}, 20 \% \mathrm{~B}$ (column equilibration). Flow rate was $1 \mathrm{~mL} / \mathrm{min}$ at $25{ }^{\circ} \mathrm{C}$. The experiment was monitored for $24 \mathrm{~h}$. Retention times were found as follows: NAG-thiazoline 1, 6.1 min; $\alpha$-GlcNAc-SH 11a, $6.8 \mathrm{~min}$; $\beta$-GlcNAc-SH 11b, $7.1 \mathrm{~min}$; oxidation products, 9-13 $\mathrm{min}$. In situ reduction of the 
products of spontaneous oxidation was performed by adding dithiothreitol $(1 \mathrm{M})$ to the reaction mixture in the final concentration of $100 \mathrm{mM}$ and monitored by HPLC and NMR.

\subsection{Analysis of Decomposition Products of NAG-Thiazoline $\mathbf{1}$}

NAG-thiazoline (1; $200 \mathrm{mg}, 0.91 \mathrm{mmol}$ ) was dissolved in $50 \mathrm{mM} \mathrm{K} \mathrm{HPO}_{4} / \mathrm{KH}_{2} \mathrm{PO}_{4}$ buffer pH 6.5 $(4 \mathrm{~mL})$ and incubated at $35{ }^{\circ} \mathrm{C}$ and $850 \mathrm{rpm}$ for $5 \mathrm{~h}$. Then, the reaction volume was reduced to $2.5 \mathrm{~mL}$ in vacuo and the reaction mixture was loaded on a Biogel P-2 column (BioRad, Prague, Czech Republic) in water, flow rate $12 \mathrm{~mL} / \mathrm{h}$. A mixture of oxidation products was isolated $(20 \mathrm{mg})$. This mixture was further practically inseparable since the compounds coexisted in equilibrium. Analysis by MS revealed the presence of masses corresponding to $\mathrm{C}_{8} \mathrm{H}_{15} \mathrm{NO}_{5} \mathrm{~S}$ calcd. 237.07, m/z [M-H] found 236.0; and to $\mathrm{C}_{16} \mathrm{H}_{28} \mathrm{~N}_{2} \mathrm{O}_{10} \mathrm{~S}_{2}$ (tentative structure GlcNAc-S-(1↔1)-S-GlcNAc) calc. 472.1, $\mathrm{m} / z$ $[\mathrm{M}-\mathrm{H}]^{-}$found 471.0 (HPLC and MS are presented in the Supplementary Information). After application of dithiothreitol, the oxidation mixture was quickly reduced to the anomeric mixture of 2-acetamido-2-deoxy-1-thio-D-glucopyranose 11a $(\alpha)$ and 11b $(\beta)$. (11a) ${ }^{1} \mathrm{H}-\mathrm{NMR}(700.13 \mathrm{MHz}$, $\mathrm{D}_{2} \mathrm{O}$ ): 1.749 (3H, s, 2-Ac), $3.136(1 \mathrm{H}, \mathrm{dd}, J=10.1,8.5 \mathrm{~Hz}, \mathrm{H}-4), 3.507$ (2H, d, $\left.J=3.7 \mathrm{~Hz}, \mathrm{H}-6\right), 3.565$ $(1 \mathrm{H}, \mathrm{dd}, J=10.5,8.5 \mathrm{~Hz}, \mathrm{H}-3), 3.685(1 \mathrm{H}, \mathrm{dd}, J=10.5,5.0 \mathrm{~Hz}, \mathrm{H}-2), 3.862(1 \mathrm{H}, \mathrm{dt}, J=10.1,3.7 \mathrm{~Hz}$, $\mathrm{H}-5), 5.272(1 \mathrm{H}, \mathrm{d}, J=5.0 \mathrm{~Hz}, \mathrm{H}-1),{ }^{13} \mathrm{C}-\mathrm{NMR}\left(176.07 \mathrm{MHz}, \mathrm{D}_{2} \mathrm{O}\right): 22.45$ (2-Ac), 55.29 (C-2), 60.93 (C-6), 70.73 (C-4), 71.37 (C-5), 71.56 (C-3), 80.37 (C-1), 174.27 (CO). (11b): ${ }^{1} \mathrm{H}-\mathrm{NMR}$ (700.13 MHz, $\left.\mathrm{D}_{2} \mathrm{O}\right): 1.742(3 \mathrm{H}, \mathrm{s}, 2-\mathrm{Ac}), 3.124(1 \mathrm{H}, \mathrm{m}, \mathrm{H}-5), 3.150(1 \mathrm{H}, \mathrm{m}, \mathrm{H}-4), 3.174(1 \mathrm{H}, \mathrm{m}, \mathrm{H}-3), 3.352(1 \mathrm{H}$, $\mathrm{dd}, J=10.0,9.9 \mathrm{~Hz}, \mathrm{H}-2), 3.396(1 \mathrm{H}, \mathrm{dd}, J=12.4,5.5 \mathrm{~Hz}, \mathrm{H}-6 \mathrm{u}), 3.577(1 \mathrm{H}, \mathrm{dd}, J=12.4,2.0 \mathrm{~Hz}$, H-6d), 4.385 (1H, d, $J=9.9 \mathrm{~Hz}, \mathrm{H}-1),{ }^{13} \mathrm{C}-\mathrm{NMR}\left(176.07 \mathrm{MHz}, \mathrm{D}_{2} \mathrm{O}\right): 22.57$ (2-Ac), $59.72(\mathrm{C}-2), 61.25$ (C-6), 70.18 (C-4), 75.78 (C-3), 80.23 (C-5), 80.69 (C-1), $174.63(\mathrm{C}=\mathrm{O})$. Results of NMR analysis of oxidation product mixture are not in contradiction with the structure GlcNAc-S- $(1 \leftrightarrow 1)-\mathrm{S}-\mathrm{GlcNAc}$ as proposed from the MS measurement.

\subsection{Enzymes}

$\beta$-N-Acetylhexosaminidase from Talaromyces flavus was extracellularly expressed in Pichia pastoris and purified from the culture media by cation exchange chromatography as described previously [12]. The gene of $\beta$ - $N$-acetylhexosaminidase from Streptomyces plicatus (GenBank ID: AF063001.3) was prepared synthetically as a His 6 -tagged fusion protein (Geneart, Regensburg, Germany) and cloned into the bacterial expression vector pET-15b via the NdeI and BamHI restriction sites. The gene was intracellularly expressed in E. coli BL21(DE3) pLysS strain (Promega, Prague, Czech Republic) under the IPTG $(0.5 \mathrm{mM})$ induction. After $16 \mathrm{~h}$ of cultivation at $25^{\circ} \mathrm{C}$, the cells were harvested by centrifugation $(4,000 \times g, 15 \mathrm{~min})$ and resuspended in a lysis buffer $(50 \mathrm{mM} \mathrm{Tris} / \mathrm{HCl}, \mathrm{pH} 7)$ with $50 \mathrm{mM} \mathrm{NaCl}, 4 \mathrm{mM} \mathrm{MgCl}_{2}, 0.5 \%$ Triton X-100, $1 \mathrm{mM}$ phenylmethylsulfonyl fluoride and lysozyme $(1 \mathrm{mg} / \mathrm{mL})$. The cells were then incubated for $30 \mathrm{~min}$ at $37{ }^{\circ} \mathrm{C}$ and disrupted with ultrasound $(6 \times 1 \mathrm{~min})$. After centrifugation $(13,500 \times g, 10 \mathrm{~min})$ the supernatant was loaded onto Ni-NTA agarose column (Qiagen by Dynex, Bustehrad, Czech Republic). The column was equilibrated with $50 \mathrm{mM}$ Tris/HCl buffer with $150 \mathrm{mM} \mathrm{KCl}$ and $10 \mathrm{mM}$ imidazole, $\mathrm{pH}$ 7.4. The fusion protein was eluted from the column using $50 \mathrm{mM}$ Tris/HCl buffer supplemented with $150 \mathrm{mM} \mathrm{KCl}$ and $250 \mathrm{mM}$ imidazole, $\mathrm{pH}$ 7.4. The purity of the fractions was determined by $10 \%$ SDS-PAGE. 
The genes of $O$-GlcNAcase from Bacteroides thetaiotaomicron and human $O$-GlcNAcase were obtained from Prof. D. Vocadlo (SFU, Burnaby, BC, Canada). The genes were intracellularly expressed in E. coli BL21(DE3) pLysS strain under the induction by IPTG $(0.5 \mathrm{mM})$. After $4 \mathrm{~h}$ of cultivation at $16{ }^{\circ} \mathrm{C}$, the cells were harvested by centrifugation $(4,000 \times g, 15 \mathrm{~min})$. The procedure for the isolation of both $O$-GlcNAcases was analogous to the purification procedure for $\beta$ - $N$-acetylhexosaminidase from Streptomyces plicatus as described above.

\section{8. $\beta$-N-Acetylhexosaminidase and O-GlcNAcase Activity and Inhibition Assays}

$\beta$ - $N$-Acetylhexosaminidase and $O$-GlcNAcase activities were assayed in end-point experiments using $p$-nitrophenyl 2-acetamido-2-deoxy- $\beta$-D-glucopyranoside ( $p$ NP- $\beta$-GlcNAc; Sigma Aldrich) as a substrate; starting concentration $2 \mathrm{mM}$. One unit of enzymatic activity was defined as the amount of enzyme releasing $1 \mu \mathrm{mol}$ of $p$-nitrophenol per minute in $50 \mathrm{mM}$ citrate-phosphate buffer at $\mathrm{pH} 7.0$ and $35{ }^{\circ} \mathrm{C}$. After incubation of the reaction mixture at $35^{\circ} \mathrm{C}$ for $10 \mathrm{~min}$, the liberated $p$-nitrophenol was determined spectrophotometrically at $420 \mathrm{~nm}$ under alkaline conditions (50 $\mu \mathrm{L}$ of the reaction mixture was added to $1 \mathrm{~mL}$ of $0.1 \mathrm{M} \mathrm{Na}_{2} \mathrm{CO}_{3}$ ).

Michaelis-Menten kinetics of $\beta$ - $N$-acetylglucosaminidase reactions was measured in a kinetic assay at $348 \mathrm{~nm}$ (isosbestic point of $p$-nitrophenol), using $p N P-\beta-G l c N A c$ as substrate with its concentration in the range of $0.04-0.5 \mathrm{mM}\left(50 \mathrm{mM}\right.$ citrate-phosphate buffer $\left.\mathrm{pH} 7.0,25^{\circ} \mathrm{C}\right)$; in the inhibition assays the concentration of the inhibitors ranged from 0.001 to $0.5 \mathrm{mM}$ for $O$-GlcNAcases and from 0.05 to $2 \mathrm{mM}$ for $\beta-N$-acetylhexosaminidases. All data were measured in five parallels; the non-linear regression was calculated using Enzfitter (Biosoft, UK). Lineweaver-Burk plots for the individual experiments are shown in the Supplementary information.

\subsection{Molecular Modeling and Docking}

C-6-azido-NAG-thiazoline (2) was constructed in YASARA by modification of the crystal structure of NAG-thiazoline (1) extracted from the enzyme/inhibitor complex of $\beta$ - $N$-acetylhexosaminidase from Streptomyces plicatus with NAG-thiazoline (pdb code: 1hp5) [13]. Quantum calculations to determine the partial charges were performed in Gaussian 03 [14] at the B3LYP/6-31G(p,d) level of theory. The resulting charges were converted to RESP charges by Antechamber [15] and included in the molecular topology to be used in YASARA. $p$ NP- $\beta$-GlcNAc was constructed in YASARA by modification of di- $N$-acetyl-D-glucosamine (chitobiose), extracted from the crystal structure of chitobiase from Serratia marcescens (pdb code: 1qbb) [16].

The substrate $p$ NP- $\beta$-GlcNAc, inhibitor C-6-azido-NAG-thiazoline (2) and NAG-thiazoline (1) were docked in the active site of selected $\beta-N$-acetylhexosaminidases (GH20) and $\beta$ - $N$-acetylglucosaminidases (GH84) using rigid docking in AutoDock 4.2 .3 [17] to accommodate them properly in the active site of enzymes, using a grid space of $0.275 \AA$, the Lamarckian genetic algorithm [18], and 100 docking runs). Structures of enzymes used for docking are listed as follows: crystal structure of $O$-GlcNAcase from Bacteroides thetaiotaomicron (pdb code: 2chn) [19]; model of human O-GlcNAcase [20]; crystal structure of $\beta-N$-acetylhexosaminidase from Streptomyces plicatus (pdb code: 1hp5) [13] and the model of $\beta$ - $N$-acetylhexosaminidase from Talaromyces flavus (will be published elsewhere). The obtained complexes with best docking scores were used for molecular dynamics simulation in water 
with YASARA (isothermal-isobaric ensemble (NPT), counter ions to reach neutrality, YASARA 2 force field [21], periodic boundary condition, long range electrostatics treated by Particle Mesh Ewald method [22]). Molecular dynamics simulations were run for more than $10 \mathrm{~ns}$ and analyzed. Root mean square deviation of all $\mathrm{C}$-alpha and of active site amino acid residues was used to asses if complexes are equilibrated. Additionally, the interaction energy from the force field was calculated during the whole simulation with YASARA to monitor if the energy reaches a stable plateau and thus indicates that the substrate/inhibitor interaction with the enzyme is stable. Finally, a set of representative structures of stable substrate/inhibitor-enzyme complexes from the last 2 ns of the equilibrated production period of the simulations was used for binding energy calculations by AutoDock and for analysis with YASARA. Interactions in the active site were shown with LigPlot+ [23] and YASARA.

\section{Conclusions}

A series of novel derivatives of GlcNAc-thiazolines substituted (compounds 2-8) or dimerized at C-6 (compounds 9-10) bearing azido or triazole moieties were designed as potential $\beta-N$-acetylhexosaminidase inhibitors and synthesized. New compounds were tested for their inhibitory activities with GH20 $\beta-N$-acetylhexosaminidases and GH84 $\beta-N$-acetylglucosaminidases. One bacterial and one eukaryotic model enzyme of each glycosidase family were selected for the inhibition study: GH20 $\beta$ - $N$-acetylhexosaminidases from Streptomyces plicatus (bacterial) and Talaromyces flavus (fungal) and GH84 $\beta$ - $N$-acetylglucosaminidases from Bacteroides thetaiotaomicron (bacterial) and humans. While all the triazole-substituted NAG-thiazolines 3-10 lacked inhibition activity with the enzymes used, the C-6-azido-NAG-thiazoline (2) inhibited most of the enzymes in a moderate way. Elaborated kinetic study was performed to compare both the original $\mathbf{1}$ and the new inhibitor $\mathbf{2}$. Molecular docking of C-6-azido-NAG-thiazoline 2 into the active site of the respective enzymes and consequent molecular dynamics simulations of the resulting complexes were performed to corroborate the conclusions obtained from the "wet" experiments with a molecular explanation. Generally, the affinity of $\beta-N$-acetylhexosaminidases to modified NAG-thiazoline $\mathbf{2}$ is lower than to the substrate having more hydrogen bonding partners. A detailed stability study with unsubstituted GlcNAc-thiazoline 1 has shown its decomposition at $\mathrm{pH}<6$ resulting in the thiazoline ring opening yielding 2-acetamido-2-deoxy-1-thio- $\alpha / \beta$-D-glucopyranoses 11a,b, which presumably dimerize oxidatively into S-S linked dimers. Tentative structures of the products were supported by mass spectrometry and NMR measurements. Decomposition products proved to have no inhibitory activity towards $\beta$ - $N$-acetylhexosaminidase ( $T$. flavus).

\section{Supplementary Materials}

Supplementary materials can be accessed at: http://www.mdpi.com/1420-3049/19/3/3471/s1.

\section{Acknowledgments}

This work was supported by the Czech Science Foundation grant P207/11/0629 and by EU project NOVOSIDES FP7-KBBE-2010-4-265854. Access to computing and storage facilities owned by parties and projects contributing to the National Grid Infrastructure MetaCentrum, provided under the 
program "Projects of Large Infrastructure for Research, Development, and Innovations" (LM2010005) is acknowledged. The authors would like to thank to D. Vocadlo (SFU, Burnaby, BC, Canada) for very kindly providing the genes of $O$-GlcNAcase from Bacteroides thetaiotaomicron and human $O$-GlcNAcase.

\section{Author Contributions}

J. Krejzová and K. Slámová prepared the enzymes and measured inhibition kinetics, P. Šimon and L. Kalachova synthesized compounds 1-10, P. Bojarová and P. Marhol performed the analysis of inhibitor stability, H. Pelantová measured and interpreted NMR, J. Cvačka measured MS, N. Kulik and R. Ettrich performed computational modeling, K. Slámová and V. Křen prepared the manuscript for publication.

\section{Conflicts of Interest}

The authors declare no conflict of interest.

\section{References}

1. Knapp, S.; Vocadlo, D.; Gao, Z.; Kirk, B.; Lou, J.; Withers, S.G. NAG-Thiazoline, an N-acetyl- $\beta$ hexosaminidase inhibitor that implicates acetamido participation. J. Am. Chem. Soc. 1996, 118, 6804-6805.

2. Slámová, K.; Bojarová, P.; Petrásková, L.; Křen, V. $\beta$-N-Acetylhexosaminidase: What's in a name...? Biotechnol. Adv. 2010, 28, 682-693.

3. Yuzwa, S.A.; Macauley, M.S.; Heinonen, J.E.; Shan, X.; Dennis, R.J.; He, Y.; Whitworth, G.E.; Stubbs, K.A.; McEachern, E.J.; Davies, G.J.; et al. A potent mechanism-inspired $O$-GlcNAcase inhibitor that blocks phosphorylation of tau in vivo. Nat. Chem. Biol. 2008, 4, 483-490.

4. Mahuran, D.J. Biochemical consequences of mutations causing the GM2 gangliosidoses. Biochim. Biophys. Acta 1999, 1455, 105-138.

5. Macauley, M.S.; Whitworth, G.E.; Debowski, A.W.; Chin, D.; Vocadlo, D.J. O-GlcNAcase uses substrate-assisted catalysis: Kinetic analysis and development of highly selective mechanisminspired inhibitors. J. Biol. Chem. 2005, 280, 25313-25322.

6. Knapp, S.; Abdo, M.; Ajayi, K.; Huhn, R.A.; Emge, T.J.; Kim, E.J.; Hanover, J.A. Tautomeric modification of GlcNAc-thiazoline. Org. Lett. 2007, 9, 2321-2324.

7. Amorelli, B.; Yang, C.; Rempel, B.; Withers, S.G.; Knapp, S. N-Acetylhexosaminidase inhibitory properties of C-1 homologated GlcNAc- and GalNAc-thiazolines. Bioorg. Med. Chem. Lett. 2008, 18, 2944-2947.

8. Krejzová, J.; Šimon, P.; Vavř́ková, E.; Slámová, K.; Pelantová, H.; Riva, S.; Spiwok, V.; Křen, V. Enzymatic synthesis of new C-6-acylated derivatives of NAG-thiazoline and evaluation of their inhibitor activities towards fungal $\beta-N$-acetylhexosaminidase. J. Mol. Catal. B-Enzym. 2013, 87, 128-134.

9. Yuzwa, S.A.; Shan, X.; Maculey, M.S.; Clark, T.; Skorobogatko, Y.; Vosseller, K.; Vocadlo, D. Increasing $O$-GlcNAc slows neurodegeneration and stabilizes tau against aggregation. $J$. Nat. Chem. Biol. 2012, 8, 393-399. 
10. Vocadlo, D.; McEachern, E.W.O. Selective Glycosidase Inhibitors and Uses Thereof. Patent 2008/025170 A1, 6 March 2008.

11. Fialová, P.; Weignerová, L.; Rauvolfová, J.; Přikrylová, V.; Pišvejcová, A.; Ettrich, R.; Kuzma, M.; Sedmera, P.; Křen, V. Hydrolytic and transglycosylation reactions of $N$-acyl modified substrates catalysed by $\beta-N$-acetylhexosaminidases. Tetrahedron 2004, 60, 693-701.

12. Slámová, K.; Bojarová, P.; Gerstorferová, D.; Fliedrová, B.; Hofmeisterová, J.; Fiala, M.; Pompach, P.; Křen, V. Sequencing, cloning and high-yield expression of a fungal $\beta-N$ acetylhexosaminidase in Pichia pastoris. Protein Expr. Purif. 2012, 82, 212-217.

13. Mark, B.L.; Vocadlo, D.J.; Knapp, S.; Triggs-Raine, B.L.; Withers, S.G.; James, M.N.G. Crystallographic evidence for substrate-assisted catalysis in a bacterial $\beta$-hexosaminidase. J. Biol. Chem. 2001, 276, 10330-10337.

14. Gaussian 03, Revision C.02; Gaussian, Inc.: Wallingford, CT, USA, 2004.

15. Wang, J.; Wang, W.; Kollmann, P.; Case, D. Antechamber, an accessory software package for molecular mechanical calculation. J. Comput. Chem. 2005, 25, 1157-1174.

16. Tews, I.; Perrakis, A.; Oppenheim, A.; Dauter, Z.; Wilson, K.S.; Vorgias, C.E. Bacterial chitobiase structure provides insight into catalytic mechanism and the basis of Tay-Sachs disease. Nat. Struct. Biol. 1996, 3, 638-648.

17. Morris, G.M.; Huey, R.; Lindstrom, W.; Sanner, M.F.; Belew, R.K.; Goodsell, D.S.; Olson, A.J. AutoDock4 and AutoDockTools4: Automated docking with selective receptor flexibility. J. Comput. Chem. 2009, 30, 2785-2791.

18. Morris, G.M.; Goodsell, D.S.; Halliday, R.S.; Huey, R.; Hart, W.E.; Belew, R.K.; Olson, A.J. Automated docking using a Lamarckian genetic algorithm and empirical binding free energy function. J. Comput. Chem. 1998, 19, 1639-1662.

19. Dennis, R.J.; Taylor, E.J.; Macauley, M.S.; Stubbs, K.A.; Turkenburg, J.P.; Hart, S.J.; Black, G.N.; Vocadlo, D.J.; Davies, G.J. Structure and mechanism of a bacterial $\beta$-glucosaminidase having O-GlcNAcase activity. Nat. Struct. Mol. Biol. 2006, 13, 365-371.

20. Slámová, K.; Kulik, N.; Fiala, M.; Krejzová-Hofmeisterová, J.; Ettrich, R.; Křen, V. Expression, characterization and homology modelling of a novel eukaryotic GH84 $\beta$ - $N$-acetylglucosaminidase fom Penicillium chrysogenum. Protein Expr. Purif. 2014, 95, 204-210.

21. Krieger, E.; Joo, K.; Lee, J.; Raman, S.; Thompson, J.; Tyka, M.; Baker, D.; Karplus, K. Improving physical realism, stereochemistry, and side-chain accuracy in homology modeling: Four approaches that performed well in CASP8. Proteins 2009, 77, 114-122.

22. Essman, U.; Perera, L.; Berkowitz, M.L.; Darden, T.; Lee, H.; Pedersen, L.G. A smooth particle mesh Ewald method. J. Chem. Phys. 1995, 103, 8577-8593.

23. Laskowski, R.A.; Swindells, M.B. LigPlot+: Multiple ligand-protein interaction diagrams for drug discovery. J. Chem. Inf. Model. 2011, 51, 2778-2786.

Sample Availability: Samples of the compounds $\mathbf{1}$ and $\mathbf{2}$ are available from the authors at the Institute of Microbilology, Prague, Czech Republic.

(C) 2014 by the authors; licensee MDPI, Basel, Switzerland. This article is an open access article distributed under the terms and conditions of the Creative Commons Attribution license (http://creativecommons.org/licenses/by/3.0/). 